\title{
Pengaruh Rawat Gabung Pasien HIV/IADS dengan Infeksi Pseudomonas Aeruginosa Terhadap Risiko Transmisi ke Pasien Lain di Ruang Dahlia II Rumah Sakit Penyakit Infeksi Prof. Dr. Sulianti Saroso
}

\author{
The Effect of Join Care of HIV/AIDS Patients with Pseudomonas \\ Aeruginosa Infectious Againt Transmission Risk to Other Patients \\ in The Dahlia II Ward at Hospital of Infectious Disease \\ Prof. Dr. Sulianti SarosoJakarta
}

\author{
Veronika Hutabarat ${ }^{1}$, Hotmarida Silalahi ${ }^{2}$ \\ RSPI Prof. Dr. Sulianti saroso
}

\begin{abstract}
Abstrak.Pseudomonas aeruginosa merupakan patogen utama bagi manusia yang disebut patogen oportunistik, bakteri ini menjadi problema serius pada pasien rumah sakit yang menangani pasien AIDS yang mengalami penurunan sistem kekebalan akibat perkembangan virus.Tujuan penelitian ini adalah untuk mengetahui pengaruh rawat gabung pasien HIV / AIDS dengan infeksi Pseudomonas aeruginosa terhadap resiko transmisi ke pasien lain di Ruang Dahlia II RSPI Sulianti Saroso Jakarta. Penelitin ini merupakan penelitian pre experimental dengan pre and posttest without control desaign. Sampel dalam penelitian ini adalah pasien HIV/AIDS dewasa yang terinfeksi dan tidak terinfeksi Pseudomonas aeruginosa sebanyak 50 responden yang diambil dengan teknik purposive sampling. Dari 60 pasien didominasi oleh kelompok usia 31-40 Tahun yaitu sebanyak 29 (48.3\%), jenis jenis kelamin laki-laki yaitu sebanyak 40 (67\%), tingkat kesadaran compos mentis yaitu sebanyak 50 (83.3 \%), jumlah CD4 < 50 yaitu sebanyak 44 (73\%), mikroorganime hasil kultur I didominasi oleh jamur sebanyak 22 (36.7\%), mikroorganisme hasil kultur II didominasi oleh Klebsiella pnumonia sebanyak 19 (31.7\%). Infeksi oportunistik pasien yaitu 56 (50\%) Tb Paru. Hasil penelitian menunjukkan bahwa tidak ada perbedaan transmisi infeksi Pseudomonas aeruginosa sebelum dan sesudah rawat gabung dengan $\mathrm{P}$ value $(1.000)>\alpha(0,05)$. Diharapkan rawat gabung pasien memperhatikan universal precaution.
\end{abstract}

Keyword : Pseudomonas Aeruginosa, rawat gabung

\begin{abstract}
Pseudomonas aeruginosa is main pathogenic for humans called pathogenic opportunistic, this bacteria is serious problem on hospital patients who handles AIDS patients have experienced decline immune systems due to the development of the virus. The purpose of this research is to know the effect of join care of HIV/AIDS patients with Pseudomonas aeruginosa infectious against transmission risk to other patients in the dahlia II ward at hospital of infectious diseases Prof. Dr. Sulianti Saroso in Jakarta.This research is the pre experimental research with pre and post-test without control design. The samples in this research were HIVIAIDS adult patients whom infected and not infected by Pseudomonas aeruginosa as many as 50 respondents taken by using purposive sampling techniques. From 60 patients whom dominated by age group 31-40 years old as many as 29 ( $48.3 \%$ ), the male gender were as many as 40 (67\%), the level of awareness is compos mentis that were as many as 50 ( $83.3 \%$ ), amount of CD4 < 50 namely as many as 44 (73\%), the results of the culture of microorganis that dominated by fungi as many as 22 (36.7\%), the results of the culture of microorganisms II that dominated by Klebsiella pnumonia were as many as 19 (31.7\%). Patients of opportinistic infectious were as many as 56 (50\%) pulmonology tuberculosis. An opportunistic infection of patients that is 56 (50 percent) pulmonary tuberculosis. The results of research stated that there is no the difference in the transmission of Pseudomonas aeruginosa infections before and after join care with $P$ value $(1.000)>\alpha(0,05)$. It is expected to join care of patients more focus and notice on universal precaution.
\end{abstract}

Keywords : Pseudomonas Aeruginosa, join care 
Korespondensi : Veronika Hutabarat

RSPI Sulianti Saroso, JI. Baru Sunter Permai

Raya Jakarta Utara 14340

Phone : 021-6506559Fax : 021-6401411

Email : emaksylvia@yahoo.com

\section{PENDAHULUAN}

Pseudomonas aeruginosa merupakan patogen utama bagi manusia sebagai patogen oportunistik yang mengambil keuntungan dari lemahnya sistem kekebalan tubuh individu untuk menimbulkan infeksi. Transmisi Pseudomonas aeruginosa dapat melalui aliran udara, air, tangan tercemar, dan penanganan alat-alat yang tidak steril di rumah sakit. Selain itu, dapat juga melalui agent hewan antara lain lalat, nyamuk, dsb. Pseudomonas aeruginosa menyebabkan infeksi saluran kemih, infeksi sistem pernafasan, dermatitis, infeksi jaringan lunak, infeksi bakteremia, tulang dan sendi, infeksi gastrointestinal dan berbagai infeksi sistemik, terutama pada pasien dengan luka bakar parah dan pada AIDS yang immunosupresi ${ }^{1}$.

Pseudomonas aeruginosa merupakan bakteri gram negatif yang bersifat patogen oportunistik karena bakteri tersebut memanfaatkan kerusakan pada pertahanan inang untuk memulai suatu infeksi, hal ini menjadikan keberadaan Pseudomonas aeruginosa menjadi masalah serius pada pasien yang menderita penyakit immunocompromise seperti kanker dan HIV/AIDS, dimana HIV/AIDS merupakan gejala penyakit yang didapat akibat menurunnya system kekebalan tubuh yang disebabkan oleh virus $\mathrm{HIV}^{2,3}$.

Pseudomonas aeruginosa dapat dijumpai di banyak tempat di rumah sakit, seperti alat bantu pernafasan, makanan, saluran pembuangan air dan kain pel. Penyebaran Pseudomonas aeruginosa melalui aliran udara, air, tangan tercemar, penanganan dan alat-alat yang tidak steril di rumah sakit. Selain itu, dapat juga lewat hewan (lalat, nyamuk, dsb) yang telah tercemar. Pseudomonas aeruginosa menyebabkan kontaminasi pada perlengkapan anestesi dan terapi pernafasan, cairan intravena, bahkan air hasil proses penyulingan ${ }^{1,3}$.

Upaya pencegahan penularan penyakit pada pasien yang dirawat di rumah sakit dilakukan dengan cara kerja steril/ aseptis yang dilakukan oleh setiap personil rumah sakit (medis dan paramedis) dengan penuh rasa tanggung jawab ${ }^{1}$.

Menurut CDC, kejadian keseluruhan infeksi Pseudomonas aeruginosa di Rumah Sakit di USA rata-rata sekitar 0,4 persen (4 per 1000 discharge) dan angka kematian bagi individu yang terinfeksi dengan Pseudomonas aeruginosa mendekati $50 \%$, sedangkan berdasarkan hasil periksaan kultur sputum mikroorganisme di Rumah Sakit Prof. Dr. Sulianti Saroso angka kejadian positif bakteri Pseudomonas aeruginosa mulai dari Januari - Juni 2011 mencapai 21\% dari kuman penyebab infeksi nasokomial ${ }^{4}$. Hingga saat ini sudah banyak yang meneliti tentang Pseudomonas aeruginosa. Hasil penelitian Clifton, et.al mengatakan bahwa transmisi bakteri pseudomonas aeruginosa sangat potensial melalui droplet sedangkan penelitian yang dilakukan oleh Jones mengatakan bahwa dalam penelitiannya menunjukkan ada kemungkinan penularan Pseudomonas aeruginosa melalui aerosol 5,6 .

Hingga saat ini pemahaman tentang bakteri Pseudomonas aeruginosa belum terlalu tinggi khususnya bagi perawat, hal in tampak dari tingginya rasa cemas perawat dalam merawat pasien yang terinfeksi Pseudomonas aeruginosa dan bahkan adanya perbedaan pendapat antara para petugas kesehatan yang mengatakan bahwa pasien yang terinfeksi Pseudomonas aeruginosa tidak boleh dirawat gabung dan ada yang mengatakan boleh dirawat gabung tetapi dengan melakukan kewaspadaan standart dengan benar.

Tingginya angka kejadian dan kegawatan yang diakibatkan transmisi bakteri ini dan banyaknya perbedaan pendapat yang mempengaruhi penatalaksanaan kepada pasien yang terinfeksi serta terbatasnya informasi terkait mekanisme dari bakteri Pseudomonas aeruginosa maka perlu 
diketahui pengaruh rawat gabung pasien HIV/AIDS dengan Pseudomonas aeruginosa terhadap resiko transmisi ke pasien lain.

Tujuan dari penelitian ini adalah mengetahui pengaruh rawat gabung pasien HIV/AIDS dengan infeksi Pseudomonas aeruginosa terhadap resiko transmisi ke pasien lain.

\section{METODOLOGI}

Penelitin ini merupakan penelitian pre experimental dengan pre and post test without control desaign. Sampel dalam penelitian ini adalah pasien HIV/AIDS dewasa yang terinfeksi dan tidak terinfeksi Pseudomonas aeruginosa sebanyak 50 responden yang memenuhi kriteria inklusi dan eksklusi. Sampel ini diambil dengan teknik purposive sampling. Penelitian dilakukan di ruang perawatan HIV yaitu Dahlia II Rumh Sakit Penyakit Penyakit Infeksi Prof. Dr. Sulianti Saroso.

Teknik pengumpulan data yang digunakan dalam penelitian ini adalah :

1. Pasien HIV/AIDS yang baru rawat dilakukan tes Pseudomonas aeruginosa melalui sampel dahak

2. Dahak tersebut selanjutnya dikirim ke Laboratorium Mikrobiologi RSPI Prof. Dr.Sulianti Saroso untuk dilakukan pemeriksaan sesuai SOP Pemeriksaan Mikrobiologi untuk mengetahui mikroorganisme dan jumlah koloni yang tumbuh. Kultur menggunakan media Mac Conkey Agar (MCA) dan Blood agar (BA), selanjutnya identifikasi kuman/ mikroorganisme dengan $K I A$, SSS, MIO, LAO, OF, Simon Sitrat, MR/VP untuk mengetahui spesies dari mikroorganisme.

3. Satu pasien yang positif (+) Pseudomonas aeruginosa dirawat gabung dengan 3 pasien yang negatif (-) Pseudomonas aeruginosa selama 4 hari

4. Pengontrolan kondisi lingkungan :

a. Kondisi udara akan dikendalikan dengan melakukan sidec ruangan sebelum pasien dimasukkan dan kolaborasi dengan bagian sanitasi kondisi air bebas bakteri khususnya bakteri Pseudomonas aeruginosa.

b. Pembersihan lantai menggunakan perbandingan Chlorin $1: 9$

c. Perawat dan dokter pada saat melakukan tindakan akan diingatkan dan diawasi dalam melakukan tindakan sesuai dengan SOP atau kewaspadaan standart

d. Penunggu wajib memakai barak dan mencuci tangan sebelum masuk ruangan pasien

5. Setelah 4 hari dilakukan tes Pseudomonas aeruginosa melalui sampel dahak.

Analisa data dalam penelitian ini meliputi analisa univariat dan bivariat. Analisa bivariat menggunakan uji McNemar karena data data kategorik dengan tabel $2 \times 2$. Uji ini digunakan untuk menguji signifikansi hipotesis komparatif 2 sampel berpasangan.

\section{HASIL}

Tabel 1. Karakteristik Pasien HIV/AIDS di Ruang Dahlia II Rumah Sakit Penyakit Infeksi Prof. Dr. Sulianti Saroso Tahun 2013

\begin{tabular}{|l|l|c|c|}
\hline No & \multicolumn{1}{|c|}{ Karakteristik } & $\mathrm{n}$ & $\%$ \\
\hline 1 & Umur & & \\
\hline & 20-30 Tahun & 22 & 36.7 \\
\hline & $31-40$ Tahun & 29 & 48.3 \\
\hline & 41-60 Tahun & 9 & 15 \\
\hline & Jumlah & $\mathbf{6 0}$ & $\mathbf{1 0 0}$ \\
\hline 2 & Jenis Kelamin & & \\
\hline & Laki-laki & 40 & 66.7 \\
\hline & Perempuan & 20 & 33.3 \\
\hline & Jumlah & $\mathbf{6 0}$ & $\mathbf{1 0 0}$ \\
\hline 3 & Kesadaran & & \\
\hline & CM & 50 & 83.3 \\
\hline & Apatis & 9 & 15 \\
\hline & Samnolen & 1 & 1.7 \\
\hline & Jumlah & $\mathbf{6 0}$ & $\mathbf{1 0 0}$ \\
\hline
\end{tabular}

Sumber : Data Primer, 2013

Berdasarkan karakteristik responden diketahui bahwa dari 60 pasien HIV/AIDS sebagian besar berusia 31-40 tahun yaitu sebanyak 29 (48.3\%), berjenis kelamin laki-laki yaitu sebanyak 40 (66.7\%) dan dengan kesadaran $\mathrm{CM}$ yaitu sebanyak 50 $(83.3 \%)$. 
Tabel 2. Hasil Pemeriksaan Laboratorium Pasien HIV/AIDS di Ruang Dahlia II Rumah Sakit Penyakit Infeksi Prof. Dr. Sulianti Saroso Tahun 2013

\begin{tabular}{|l|l|c|c|}
\hline No & \multicolumn{1}{|c|}{ Hasil Lab } & $\mathrm{n}$ & $\%$ \\
\hline 1 & Jumlah CD4 & & \\
\hline & $<50$ & 44 & 73.3 \\
\hline & $51-100$ & 9 & 15.0 \\
\hline & $>100$ & 7 & 11.7 \\
\hline & Jumlah & 60 & $\mathbf{1 0 0}$ \\
\hline 2 & Mikroorganisme Kultur I & & \\
\hline & $\begin{array}{l}\text { Pseudomonas } \\
\text { aeruginosa }\end{array}$ & 14 & 23.3 \\
\hline & Pseudomonas peptide & 1 & 1.7 \\
\hline & Klebsiella pneumonia & 7 & 11.7 \\
\hline & Jamur & 22 & 36.7 \\
\hline & Acinetobacter anitratus & 1 & 1.7 \\
\hline & Tidak tumbuh & 15 & 25 \\
\hline & Jumlah & 60 & $\mathbf{1 0 0}$ \\
\hline 3 & Mikroorganisme Kultur II & 14 & 23.3 \\
\hline & $\begin{array}{l}\text { Pseudomonas } \\
\text { aeruginosa }\end{array}$ & 14 & 1 \\
\hline & Pseudomonas peptide & 1 & 1.7 \\
\hline & Klebsiella pneumonia & 19 & 31.7 \\
\hline & Jamur & 9 & 15.0 \\
\hline & Acinetobacter anitratus & 2 & 3.3 \\
\hline & Tidak tumbuh & 15 & 25 \\
\hline & Jumlah & $\mathbf{6 0}$ & $\mathbf{1 0 0}$ \\
\hline
\end{tabular}

Sumber : Data Primer, 2013
Jumlah CD4 pada pasien HIV/AIDS sebagian besar < 50 (73.3\%). Hasil Kultur mikroorganisme I sebagian besar yang tumbuh adalah jamur (36.7\%). Hasil Kultur mikroorganisme II sebagian besar yang tumbuh adalah Klebsiella Pneumonia (31.7\%).

Tabel 3. Infeksi Oportunistik pada Pasien HIV/AIDS di Ruang Dahlia II Rumah Sakit Penyakit Infeksi Prof. Dr. Sulianti Saroso Tahun 2013

\begin{tabular}{|l|c|c|}
\hline \multicolumn{1}{|c|}{ Infeksi Oportunistik } & $\mathrm{n}$ & $\%$ \\
\hline Tb Paru & 56 & 50 \\
\hline Pneumonia & 5 & 4.5 \\
\hline Diare & 25 & 22.3 \\
\hline Pneumo thorax & 1 & 0.9 \\
\hline Co & 7 & 6.2 \\
\hline Toxoplasma & 17 & 15.2 \\
\hline Criptococus & 1 & 0.9 \\
\hline Jumlah & $\mathbf{1 1 2}$ & $\mathbf{1 0 0}$ \\
\hline
\end{tabular}

Sumber : Data Primer, 2013

Dari 112 infeksi oportunistik pada 60 pasien HIV/AIDS sebagian besar yaitu 56 $(50 \%)$ menderita TB Paru.

Tabel 4. Pengaruh rawat gabung terhadap transmisi penularan Pseudomonas aeruginosa di Ruang Dahlia II Rumah Sakit Penyakit Infeksi Prof. Dr. Sulianti Saroso Tahun 2013

\begin{tabular}{|c|c|c|c|c|}
\hline \multirow[t]{2}{*}{ Sebelum rawat gabung } & \multicolumn{2}{|c|}{ Sesudah rawat gabung } & \multirow{2}{*}{ Total } & \multirow[t]{2}{*}{ Pvalue } \\
\hline & $\begin{array}{c}\text { Pseudomonas } \\
\text { aeruginosa }\end{array}$ & $\begin{array}{c}\text { Bukan Pseudomonas } \\
\text { aeruginosa }\end{array}$ & & \\
\hline Pseudomonas aeruginosa & 14 & 0 & 14 & \multirow[t]{3}{*}{1.000} \\
\hline $\begin{array}{c}\text { Bukan Pseudomonas } \\
\text { aeruginosa }\end{array}$ & 0 & 46 & 46 & \\
\hline Total & 14 & 46 & 60 & \\
\hline
\end{tabular}

Sumber : Data Primer, 2013

Dari 60 pasien HIV/AIDS di ruang Dahlia II keseluruhanya yaitu 60 orang yang mengalami infeksi yng sama sebelum dan sesudah dilakukan rawat gabung. Hasil uji McNemar diperoleh Pvalue $=1.000(<$ alpha 5\%) maka dapat diambil kesimpulan bahwa rawat gabung tidak memberikan pengaruh terhadap transmisi penularan Pseudomonas aeruginosa di Ruang Dahlia II Rumah Sakit Penyakit Infeksi Prof. Dr. Sulianti Saroso.

\section{PEMBAHASAN}

Dari hasil analisa penelitian diruangan dahlia 2 RS sulianti Saroso Jakarta utara diketahui bahwa dari 60 pasien HIV/ AIDS 15 orang positif Pseudomonas aeruginosa dirawat gabung dengan 45 orang negatif Pseudomonas aeruginosa dilakukan rawat gabung selama 3-5 hari sesuai dengan masa inkubasi bakteri Pseudomonas aeruginosa yang didominasi kelompok usia produktif yaitu 31 - 40 tahun sebanyak $48.3 \%$ dan dengan jenis kelamin laki - laki sebanyak $66.7 \%$. 
Bakteri Pseudomonas aeruginosa merupakan dapat berkembang biak dengan cepat pada immunitas yang rendah ${ }^{1}$, tingkat kesadaran merupakan indikator status immunitas pasien, sedangkan pada penelitian ini didominasi tingkat kesadaran CM (compos mentis) yaitu sebanyak 50 pasien ( $83 \%$ ) hanya 10 pasien $(17 \%)$ tingkat kesadaran apatis dan somnolen. Jumlah CD4 merupakan merupakan ukuran sistem kekebalan tubuh yang mempengaruhi kemungkinan berbagai bakteri akan berkembang biak, nilai normal CD4 adalah 410 - 1590 sedangkan pada penelitian ini terdapat sebanyak $73 \%$ jumlah CD4 < 50, infeksi opportunistik merupakan infeksi oleh berbagai mikroorganisme akibat penurunan immunitas pada pasien HIV/AIDS indikator immunitas yang paling rendah pada saat sudah mencapai tingkatan stadium 4.

Berdasarkan karakteristik diatas pasien HIV/AIDS tersebut termasuk dalam imunocompromise yang memungkinkan bakteri atau virus bisa berkembang dengan cepat ${ }^{7}$.

Dari hasil analisis didapatkan dari 60 pasien HIV/AIDS di ruang dahlia 2 keseluruhanya yaitu 60 orang yang mengalami infeksi sama sebelum dan sesudah dilakukan rawat gabung. Hasil uji McNemar diperoleh $\mathrm{P}$ value (1.000) $>\alpha$ $(0,05)$ maka $\mathrm{HO}$ diterima artinya tidak ada perbedaan tranmisi infeksi Pseudomonas aeruginosa sebelum dan sesudah rawat gabung.

Dalam penelitian ini selama rawat gabung 3-5 hari tidak memberikan bukti bahwa terjadi transmisi Pseudomonas aeruginosa hal bisa disebabkan karena ukuran Pseudomonas aeruginosa 0,6 × 2 $\mu m$ sehingga tidak memungkinkan menular melalui udara. Dan juga tenaga kesehatan yang memberikan asuhan sesuai dengan SPO penanganan penyakit infeksi.

Menurut Amar bahwa transmisi dari sumber endogen dapat berasal dari ukuran $<5 \mathrm{~mm}$, dapat bertahan di udara dalam jangka panjang dan dapat berpindah jarak jauh ${ }^{8}$.

Pseudomonas aeruginosa adalah bakteri berbentuk batang dengan ukuran sekitar 0,6 × $2 \mu \mathrm{m}$. Bakteri ini terlihat sebagai bakteri tunggal, berpasangan, dan terkadang membentuk rantai yang pendek. Pseudomonas aeruginosa termasuk bakteri gram negatif, sehingga bakteri pseudomonas aeruginosa tidak bias ${ }^{1,9}$.

Penelitian serupa dilakukan oleh J.Schmid, L.J. Ling yang menyatakan bahwa tidak ada bukti penularan yang ditemukan disalah satu klinik di New Zealand. Tiga strain Pseudomonas aeruginosa diyakini menular melalui transmisi antara pasien pada klinik di Australia dan British dan tidak ada bukti yang pasti penyebarannya di New Zealand $^{10}$.

Jones A M; Govan J R W tahun 2003, mengatakan bahwa penyebaran melalui aerosol merupakan faktor yang paling penting pada pasien-pasien strain Pseudomonas Aeruginosa selama cross infection outbreak di pusat-pusat CF dewasa ${ }^{6}$.

\section{KESIMPULAN}

Dapat disimpulkan bahwa pasien yang terinfeksi Pseudomonas aeruginosa dapat dirawat gabung dengan pasien yang tidak terinfeksi Pseudomonas aeruginosa dengan memperhatikan universal precaution dan pelaksanaan sesuai Standar Prosedur Operasional (SPO).

\section{DAFTAR PUSTAKA}

1. Natalia, Pseudomonas Aruginosa. http://www.scribd.com/doc/100213857 / Pseudomonas-aeruginosa. 2008

2. Wilson;2005. Diunduh pada http:// www.pnas.org/content/102/42/14943. short.

3. Boel, Trelia, Psedomonas aeruginosa ;2004,diunduh pada http :// library.usu.ac.id

4. Rumah Sakit Prof Dr. Sulianti Saroso, Laporan PPI;2011

5. Clifton IJ, Peckham DG, Defining routes of airborne transmission of Pseudomonas aeruginosa in people with cystic fibrosis, Departement of Respiratory Medecine, St. James University Hospital, Leeds, LS97TF,UK. 
6. Jones A M; Govan J R W. Identification of airborne dissemination of epidemic multiresistant strains of Pseudomonas aeruginosa at a CF centre during a cross infection outbreak. 2003. Availabel at ; http//thorax.bmj.com/ content/58/6/525.abstract.

7. Benson CA, et al. Treating opportunistic infections among HIVinfected adults and adolescents recommenations from CDC, the National Institute of Helath, and the HIV Medecine Associations/Infectious Disease Society of America. Availabel at;http://www.cdc.gov/hiv/topics/treat ment/index.htm.

8. Amar W, Adisastomo \& Sri, R. Infeksi Bakteri Gram Negatif di ICU anak : epidemiologi, manejemen antibiotik dan pencegahan. Sari Pediatri, Vol. 6, No. 1, Juni 2004: 32-3

9. Jawetz,1996,Mikrobiologi Kedokteran, EGC, Jakarta.

10. Schmid, L.J. Ling. Pseudomonas aeruginosa transmission is infrequent in New Zealand cystic fibrosis clinics; 2010.Availabel at;http://erj. ersjournal. com/content/32/6/1583. Short. 